\title{
Quality of life of ostomized person: relationship with the care provided in stomatherapy nursing consultation
}

\author{
Qualidade de vida da pessoa estomizada: relação com os cuidados prestados na consulta de \\ enfermagem de estomaterapia

\section{Calidad de vida de la persona ostomizada: relación con los cuidados prestados en la consulta de enfermería de estomaterapia}

\section{Liliana Sofia Grilo Miranda ${ }^{1}$ \\ Amâncio António de Sousa Carvalho ${ }^{2}$ Elisabete Pimenta Araújo Paz ${ }^{3}$ (C)}

1. Centro Hospitalar de Trás-os-Montes e Alto Douro EPE. Vila Real, Portugal.

2. Universidade de Trás-os-Montes e Alto Douro. Vila Real, Portugal.

3. Universidade Federal do Rio de Janeiro. Rio de Janeiro, RJ, Brasil.
Corresponding author:

Amâncio António de Sousa Carvalho.

E-mail: amancioc@utad.pt

Submitted on $03 / 21 / 2018$.

Accepted on $07 / 24 / 2018$.

DOI: 10.1590/2177-9465-EAN-2018-0075

\begin{abstract}
Objective: To analyze the relationship between the Quality of Life (QoL) and the stomatherapy nursing consultation. Method: Descriptive-correlational study with 100 ostomized adult participants, to whom a form was applied. The data were treated with SPSS software version 20.0. Results: Most ostomized (67\%) presented a positive perception of QoL. This differed significantly $(p<0.05)$ between the types of ostomy and previous preparation in the consultation, as the colostomy patients and the individuals who booked the appointment of the stoma previously during the consultation had a better QoL. Conclusions: There is a statistical relationship between QoL, the type of ostomy and the participation in the stomatherapy nursing consultation, demonstrating the positive influence of nursing care for the ostomized. The study reinforces the importance of consultation for the adaptation of ostomized people to the new condition and improvement of their QoL.
\end{abstract}

Keywords: Quality of life; Ostomy; Nursing in Community Health.

\section{ResUmo}

Objetivos: Analisar a relação entre a Qualidade de Vida (QV) e os cuidados prestados na consulta de enfermagem de estomaterapia. Método: Estudo descritivo-correlacional, com 100 participantes adultos estomizados, aos quais foi aplicado um formulário. Os dados foram tratados com o software SPSS versão 20.0. Resultados: A maioria dos estomizados (67\%) apresentava uma QV positiva. Esta diferiu significativamente $(p<0,05)$ entre os tipos de estomia e a preparação prévia na consulta, sendo que os portadores de colostomia e os que fizeram marcação prévia do estoma na consulta apresentavam melhor QV. Conclusões: Existe relação estatística entre QV, o tipo de estomia e participação na consulta de enfermagem de estomaterapia, demonstrando a influência positiva dos cuidados de Enfermagem para o estomizado. $O$ estudo reforça a importância dessa consulta para a adaptação de estomizados à nova condição e melhoria da sua QV.

Palavras-chave: Qualidade de vida; Estomia; Enfermagem em Saúde Comunitária.

\section{Resumen}

Objetivo: Analizar la relación entre la Calidad de Vida (CV) y los cuidados prestados en la consulta de enfermería de estomaterapia. Método: Estudio descriptivo-correlacional, con 100 participantes adultos ostomizados, a los cuales se aplicó un cuestionario Los datos fueron tratados con el Software SPSS versión 20.0. Resultados: La mayoría de los ostomizados (67\%) presentaba una CV positiva. Esta ha diferido significativamente $(p<0,05)$ entre los tipos de ostomía y la preparación previa en la consulta, siendo que los portadores de colostomía y los que hicieron marcación previa del estoma en la consulta, presentaban mejor $\mathrm{CV}$. Conclusiones: Hay relación estadística entre $\mathrm{CV}$, tipo de ostomía y participación en la consulta de enfermería de estomaterapia, demostrando la influencia positiva de los cuidados de enfermería para el ostomizado. El estudio refuerza la importancia de la consulta para la adaptación de los ostomizados frente a la nueva condición y mejora de su CV.

Palabras clave: Calidad de vida; Ostomía; Enfermería en Salud Comunitaria. 


\section{INTRODUCTION}

In Portugal, according to the Portuguese Ostomized Association (Associação Portuguesa de Ostomizados), in 2009 there were approximately 12 thousand people with ostomies of all kinds, resulting in an incidence of $0.12 \%$ of ostomized population or nearly $1 / 1000 .^{1}$

According to the literature it was verified that in 100 ostomies of all types, 90 are intestinal elimination, estimating that there were approximately 13 thousand people with intestinal elimination ostomies in Portugal in the year 2012, ${ }^{2}$ which shows an increase in the prevalence of this condition.

The intestinal elimination ostomies can be classified as jejunostomies, ileostomies and colostomies, temporary and/or definitive. Each of these types of ostomies has their own specificities for stool consistency, specific care, collection material, complications and special requirements for adapting to lifestyles.

On the other hand, the pathologies that can lead to a surgical intervention that can result in the construction of an intestinal elimination ostomy; they are: i) Colon and rectum neoplasms (obstruction); ii) Diverticulitis; iii) Intestinal perforation; iv) Fistulas (anal, rectovaginal and rectourethral); v) Inflammatory bowel diseases (ulcerative colitis and Crohn's disease); vi) Congenital diseases (Hirschsprung's disease, adenomatous polyposis). ${ }^{3}$

A study carried out with 114 individuals with intestinal ostomies concluded that the predominant cause for the construction of a definitive stoma were neoplasms (81.4\%), and for a temporary stoma, anorectal trauma. ${ }^{4}$ Knowing that the cause with a higher incidence of ostomized persons is related to the colorectal cancer, it is important to emphasize and study the incidence of this group. According to data from the Globocan 2008 report of the International Agency for Research on Oncologic Disease (IARC), rectal cancer was the third most common form of neoplasm in men $(663,904$ cases, $10 \%$ of the total) and the second (571,204 cases, $9.4 \%$ of the total) worldwide. In Portugal, this type of neoplasm is also the most frequent. ${ }^{5}$

The impact of the presence of the stoma determines a change in the body image that allows the appearance of several reactions, besides the loss of part of the body experienced by the person. The onset of the ostomy requires major personal transformations, and stress may occur when demands that overwhelm or exceed an individual's adaptive capacities arise. ${ }^{6}$

The morbidity associated with surgery to perform a stoma also includes a significant effect on the Quality of Life (QoL) of the patient. ${ }^{7}$ A study carried out in the Northeastern region of Portugal, ${ }^{8}$ with a sample of 105 patients with ostomies, revealed that the QoL of most of the ostomated patients was positive, although they felt a negative impact on the work activity, with abandonment of work, reduction of sexual activity and adequacy of the diet to their new lifestyle.
In turn, a study conducted in Romania, ${ }^{9}$ in which 56 patients diagnosed with colorectal cancer concluded that the ostomy continues to have a negative impact on patients' QoL, which were influenced by several factors, such as ostomy etiology, stoma location and depression caused by the disease and the presence of the stoma. The QoL of a sample of 76 stoma patients in China $^{10}$ was not ideal, as patients experienced difficulties related to labor, social situations, sexuality, body image, and functioning of the stoma. Another study carried out in Brazil ${ }^{11}$ with 70 ostomized patients showed that participants had a decrease in QoL and faced several changes in their daily life at physiological, psychological, emotional, and social levels.

The ostomised patient requires specialized and differentiated nursing care, considering all the repercussions that this condition implies in their lives: $35 \%$ stopped working, $98 \%$ reported problems in sexual life, ${ }^{12} 78.5 \%$ had physical complications in the integrity of the skin, and stoma manifesting itself in the form of post-stomal complications. ${ }^{13}$

With regard to nursing care, the nursing consultation in stomatherapy aims to follow the ostomy patients from the preoperative to its autonomy, minimizing and solving the underlying problems, helping patients and their family in rehabilitation and obtaining the best QoL, since the persons experiencing new situations such as the case of the stoma, suffer a potential maladjustment and nurses are professionals that positively impact this transition process that requires acceptance and adaptation to the new condition of life. ${ }^{14}$

The study called "epidemiology-research-care-in-ostomy (epic)" carried out in Portugal between 2004 and 2009 showed that the information and counseling that best meet the needs of the ostomized persons comes from nurses with specific training in stomatherapy (47\%), followed by the doctor-surgeon (16\%) and the hospital nurses (14\%). ${ }^{15}$

Another study carried out in England showed that the stomated patients who had a stomatherapy nursing consultation in the preoperative period presented lower rates of ostomy complications and lower postoperative anxiety. ${ }^{16}$

The performance of an ostomy involves, whenever possible and prior to surgery, choosing and scheduling the likely location for the stoma. The stoma appointment should be performed by the stoma nurse, if possible in the presence of the surgeon, and the main objective is the appropriate choice of the stoma site so that patients become autonomous and independent in their care, thus promoting self-care. In addition, a good location for the stoma will allow a good adhesion of the collecting device. ${ }^{17}$

The requirements, verified by the ostomized person, lead to a rethinking of the necessary care for a greater efficiency in the performance of the nursing professionals, promoting the articulation of services and the continuity of care to the person, family, and community. ${ }^{18}$ 
The stomatherapy nursing consultation was not yet a reality in all Portuguese hospitals in 2016, even in the main cities of the coast, ${ }^{19,20}$ but mainly in the countryside cities, in which recently the awakening to the importance of the implementation of this consultation had started. ${ }^{8}$ Also, in 2016, the body responsible for developing guidelines for Portugal, ${ }^{21}$ for the health sector, issued recommendations for the implementation of the stomatherapy consultation. The stomated patients consider that the support received from the stoma therapist nurse in the health units in which this consultation exists is very important.

In Portugal and specifically in the interior of the North, research on the QoL of stomated patients is almost non-existent, and it is pertinent to know the perception of people with stoma in terms of their QoL, so that nursing care can be more specific to individual and family reality and provide an essential support in the health-disease transition in a community context.

This study appears in this scope of concern, and for this the following objectives were defined: i) to evaluate the impact of the ostomy on the QoL of stomated individuals; ii) to analyze the relationship between $Q$ oL and care provided in the stomatherapy nursing consultation.

\section{METHOD}

This is a descriptive-correlational and cross-sectional study, using a quantitative approach. ${ }^{22}$ The study population is composed by 100 individuals, the total number of people with intestinal elimination ostomies accompanied at the stomatherapy nursing consultation of the External Consultation Service of a North Hospital Center in the countryside of Portugal, at the date of data collection.

The inclusion criteria were defined as: i) having an intestinal elimination stoma; ii) being accompanied at the stomatherapy nursing consultation of the hospital center. As exclusion criteria, it was considered: i) not to present an intact cognitive level assessed through the Folstein scale; ii) not to understand Portuguese spoken. The entire population met these criteria. Because it is a small population, no sampling technique was applied, including the whole population with intestinal ostomies.

The Folstein scale measures the severity of cognitive loss at a specific time and follows the course of cognitive changes in an individual in time, containing eleven items, divided into two sections. The first requires verbal responses to questions of orientation, memory, and attention; the second, reading and writing in terms of naming skills, following verbal and written commands, writing a sentence and copying a drawing (polygons). The score ranges from zero to thirty points. From 0 to 22 points is equivalent to $0-2$ years of schooling; between 23 and 24 points is equivalent to 3-6 years of schooling; and 27 or more points is equivalent to 7 or more years of schooling. ${ }^{23}$ Participants with less than 22 points were to be excluded; however, all participants achieved a higher score.
As a data collection instrument, a four-part form was used: part I aimed at obtaining sociodemographic data; Part II characterizes the socio-economic level; Part III included the Quality of life questionnaire for a patient with an ostomy scale ${ }^{24}$ and intended to evaluate the participants' QoL; the fourth and last part was constituted by questions related to the follow-up of the patients in the consultation of stomatherapy nursing.

The ostomy QoL assessment scale, validated for the Portuguese language, ${ }^{25}$ consists of 34 closed questions with three options: yes, no and does not apply, organized into several themes (work, social support, sexual activity, psychological support, clothing, nutritional implications, daily care with the stoma, and type of stool used), the purpose of which is to assess the impact of the stoma on a person's lifestyle. The second part of this scale intends to evaluate the impact of the ostomy in person's QoL and includes 43 items, organized in four domains as follows: i) Physical Welfare Domain - items 1 to 11 ; ii) Psychological Welfare Domain - items 12 to 24; iii) Social Welfare Domain items 25 to 36; iv) Spiritual Welfare Area - items 37 to 43 . This article focuses only on the overall QoL, which includes the total score of 43 items from the four domains, from the second part of the scale. Responses are coded in a score from 0 to 10 , where 0 corresponds to poor or very poor QoL and 10 to great or excellent QoL.The scores of items 1 to $12,15,18,19,22$ to 30,32 to 34 and 37 were reversed, according to the authors' indications, since the score 10 was attributed to situations of worse QoL. The form was filled out during the stomatherapy nursing consultation, applied by the researchers, in a reserved area, ensuring the privacy of the person. The survey was developed between August 2012 and July 2013

The data were collected from September to October 2012 and stored in a database built specifically for this purpose. The completion of the database took place in November 2012, from which data analysis began. The database is in the repository of the University of Trás-dos-Montes and Alto Douro ${ }^{26}$ https://repositorio.utad.pt/handle/10348/2919.

Data were processed through the Statistical Package for Social Science (SPSS), version 20, with absolute and relative frequency calculations for all variables under study and measures of central tendency and dispersion for the variables ratio. For the inferential statistical treatment, we used the t Student and Anova parametric tests and, alternatively, the non-parametric Kruskal Wallis and Mann Whitney tests were used. The level of significance adopted for all tests was $5 \% .{ }^{27}$

A prior favorable opinion of the study was obtained from the Ethics Committee and Board of Directors of the hospital, through the study context (protocol dated 08/08/2012 without numbering), for its accomplishment. Free and informed consent for participation in the study was requested to all participants in the data collection phase. 


\section{RESULTS}

At first, the sociodemographic characterization of the participants is presented, followed by the characterization of the ostomies and results related to the participants' QoL.

Sociodemographic characterization of participants - Of the total number of participants, the majority were male $(62 \%)$, belonged to the $65-90$ age group ( $65 \%$ ), had the first cycle of basic education (54\%), was retired as to the labor condition $(78 \%)$ and were in the middle class (83\%) (Table 1). The mean age was 68 \pm 12.8 years (data not shown in the table).

Regarding the characteristics of the ostomies, the predominant type of stoma in our study was colostomy $(79 \%)$, permanent $(81 \%)$, and Neoplasm was the most prevalent etiological cause for the construction of an intestinal elimination ostomy (73\%). Most of the participants did not have stomatherapy consultation prior to the construction of the stoma ( $86 \%$ ), but $55 \%$ acknowledged that they had the stoma construction site marked (Table 2).

Table 1. \% Sociodemographic characterization of participants, Vila Real, Portugal $(n=100)$

\begin{tabular}{lcc}
\hline Variables & N & \% \\
\hline Sex & & \\
\hline Male & 62 & 62.0 \\
Female & 38 & 38.0 \\
\hline Age Group & & \\
\hline $30-64$ years & 35 & 35.0 \\
65-90 years & 65 & 65.0 \\
\hline Academic Qualification or Schooling( $\left.{ }^{*}\right)$ & & \\
\hline Can read and write & 22 & 22.0 \\
$1^{\text {st }}$ cycle of elementary education & 54 & 54.0 \\
$2^{\text {nd }}$ cycle of elementary education & 8 & 8.0 \\
$3^{\text {rd }}$ cycle of elementary education & 10 & 10.0 \\
High school & 3 & 3.0 \\
Higher education & 3 & 3.0 \\
\hline Professional status* & & \\
\hline Employee & 1 & 1.0 \\
Unemployed & 6 & 6.0 \\
Retired & 78 & $\mathbf{7 8 . 0}$ \\
Low & 10 & 10.0 \\
Never worked & 5 & 5.0 \\
\hline Socioeconomic level* & & \\
\hline Class I - upper & 5 & 5.0 \\
Class II - middle to upper class & 12 & 12.0 \\
Class III - middle & 83 & $\mathbf{8 3 . 0}$ \\
\hline Total & $\mathbf{1 0 0}$ & $\mathbf{1 0 0 . 0}$ \\
\hline Souce Prepared by the auths, & & \\
\hline
\end{tabular}

Source: Prepared by the authors, ${ }^{*}$ based on studies by Miranda ${ }^{26}$
Table 2. \% Characterization of the ostomies and participation in the nursing consultation, Vila Real, Portugal $(n=100)$

\begin{tabular}{|c|c|c|}
\hline Variables & $\mathbf{N}$ & $\%$ \\
\hline \multicolumn{3}{|l|}{ Type of ostomy* } \\
\hline Jejunostomy & 1 & 1.0 \\
\hline Ileostomy & 20 & 20.0 \\
\hline Colostomy & 79 & 79.0 \\
\hline \multicolumn{3}{|l|}{ length of stay* } \\
\hline Permanent & 81 & 81.0 \\
\hline Temporary & 17 & 17.0 \\
\hline Palliative & 2 & 2.0 \\
\hline \multicolumn{3}{|l|}{ Etiology* } \\
\hline Neoplasm & 73 & 73.0 \\
\hline Fistula & 3 & 3 \\
\hline Intestinal perforation & 8 & 8.0 \\
\hline Diverticulitis & 4 & 4.0 \\
\hline Inflammatory bowel disease & 4 & 4.0 \\
\hline Other & 8 & 8.0 \\
\hline \multicolumn{3}{|c|}{$\begin{array}{l}\text { Stomatherapy nursing consultation } \\
\text { prior to stoma construction }\end{array}$} \\
\hline Yes & 14 & 14.0 \\
\hline No & 86 & 86.0 \\
\hline \multicolumn{3}{|c|}{$\begin{array}{l}\text { Has the stoma construction site been } \\
\text { previously marked? }\end{array}$} \\
\hline Yes & 55 & 55.0 \\
\hline No & 45 & 45.0 \\
\hline
\end{tabular}

In the evaluation of changes in labor, sexual, clothing, and food activities, after ostomy changes were evident, since $99 \%$ of the subjects did not work full-time and $100 \%$ part-time, including $28 \%$ who no longer worked due to the ostomy. Regarding sexual activity, it was observed that $48 \%$ of the individuals who were sexually active before the stoma reduced sexual activity after the same, since they admitted to being dissatisfied at present $(44 \%)$, and $88.7 \%$ of the men said they had erection problems or difficulty maintaining it. As for clothing, the majority of participants (56\%) reported that they did not have to change their dress style due to the ostomy. Regarding food, it was observed that the majority $(57 \%)$ did not readjust their diet because of the ostomies, nor did they change their diet to prevent the emission of gases in public (64\%). However they reported avoiding drinking gas $(91 \%)$ and eating snacks ( $87 \%$ ) (Table 3 ).

Quality of life of participants - The total score of the QoL scale ranges from 0 to 430 points. The mean QoL score was $257.81 \pm 71.029$ points, the minimum 94 and the maximum 392 
Table 3. \% Ostomy impact on labor, sexual, clothing and food activities, Vila Real, Portugal $(n=100)$

\begin{tabular}{|c|c|c|c|c|c|c|c|}
\hline \multirow{2}{*}{ Variables } & \multirow{2}{*}{ Items } & \multicolumn{2}{|c|}{ No } & \multicolumn{2}{|c|}{ Yes } & \multicolumn{2}{|c|}{ Not applicable } \\
\hline & & $\mathbf{N}$ & $\%$ & $\mathbf{N}$ & $\%$ & $\mathbf{N}$ & $\%$ \\
\hline \multirow{3}{*}{ Work activity } & Do you work full time? & 99 & 99.0 & 1 & 1.0 & 0 & 0.0 \\
\hline & Do you work part time? & 100 & 100.0 & 0 & 0.0 & 0 & 0.0 \\
\hline & Did you stop working because of the stoma? & 72 & 72.0 & 28 & 28.0 & 0 & 0.0 \\
\hline \multirow{4}{*}{$\begin{array}{l}\text { Sexual } \\
\text { Activity* }\end{array}$} & Were you sexually active before surgery? & 52 & 52.0 & 48 & 48.0 & 0 & 0.0 \\
\hline & $\begin{array}{l}\text { Did you reduce your sexual activity after having a } \\
\text { stoma? }\end{array}$ & 37 & 37.0 & 48 & 48.0 & 15 & 15.0 \\
\hline & Are you satisfied with your sexual activity? & 44 & 44.0 & 10 & 10.0 & 46 & 46.0 \\
\hline & $\begin{array}{l}\text { If you are a man, do you have problems with } \\
\text { erection or maintenance? }\end{array}$ & 7 & 11.3 & 55 & 88.7 & 0 & 0.0 \\
\hline \multirow{2}{*}{ Clothing* } & $\begin{array}{l}\text { Does the location of the ostomy cause you } \\
\text { problems? }\end{array}$ & 62 & 62.0 & 38 & 38.0 & 0 & 0.0 \\
\hline & $\begin{array}{l}\text { Did you have to change the style of your clothing } \\
\text { due to the stoma? }\end{array}$ & 56 & 56.0 & 44 & 44.0 & 0 & 0.0 \\
\hline \multirow{7}{*}{ Food* } & Did you readjust your food because of your stoma? & 57 & 57.0 & 43 & 43.0 & 0 & 0.0 \\
\hline & $\begin{array}{l}\text { Did you change your diet to prevent the emission } \\
\text { of gas in public? }\end{array}$ & 64 & 64.0 & 36 & 36.0 & 0 & 0.0 \\
\hline & Do not drink soda? & 9 & 9.0 & 91 & 91.0 & 0 & 0.0 \\
\hline & Do you avoid eating dairy products? & 78 & 78.0 & 22 & 22.0 & 0 & 0.0 \\
\hline & Do you avoid eating fruits? & 100 & 100.0 & 0 & 0.0 & 0 & 0.0 \\
\hline & Do you avoid eating snacks? & 12 & 12.0 & 87 & 87.0 & 1 & 1.0 \\
\hline & Do you avoid eating vegetables? & 98 & 98.0 & 2 & 2.0 & 0 & 0.0 \\
\hline
\end{tabular}

Source: Prepared by the authors, * based on studies by Miranda ${ }^{26}$

points. If it is taken into account the midpoint of the scale score (215 points) as a cut-off point in the categorization of QoL, it is found that the majority of study participants (67\%) had a positive and reasonable QoL.

In the coding of 0 to 10 points the mean of the QoL was 5.996 \pm 1.652 points, the minimum was of 2.19 and the maximum was of 9.12 points, also located slightly above the midpoint.

The mean of the QoL score did not differ significantly in terms of sex (Student $t: p \geq 0.645$ ), age group (Student $t: p \geq 0.163$ ), academic qualifications (ANOVA: $p \geq 0.940$ ) and socioeconomic status (Kruskal-Wallis: $p \geq 0.295$ ).

There were statistically significant differences between the mean scores of the different etiologies for the construction of an intestinal elimination ostomy (Student's t: $p<0.005)$, types of stoma (Kruskal-Wallis: $p<0,035$ ), as to taking advantage of previous preparation (Mann-Whitney: $p<0,000$ ) and if the stoma was previously marked (Student's t: $p<0.000$ ), among the participants whose stoma etiology was the neoplasm, the colostomy patients, the stomated patients who had previous preparation and the stoma marking presented a better QoL (Table 4).

\section{DISCUSSION}

The predominance of males was predictable, since in Portugal, males are the most affected by diseases of the digestive system. ${ }^{28}$ It was also predicted that the age group over 65 would be the most prevalent, not only because of the increase in average life expectancy, but also because it is the age group with the highest incidence of colorectal neoplasm, the main etiology for confection of an intestinal elimination stoma.

A study carried out in Portugal, also in the northern region, with a sample of 112 colostomized men, found that the majority belonged to the age group 32-64 (87.5\%), had the first cycle of basic education (43.7\%), was married (83.9\%), was retired $(67.9 \%)$ and was middle class $(58.0 \%) .{ }^{29}$ This study in all these sociodemographic characteristics differs only in the age group, since our population included older people, which may be because the study, in comparison, consists of a sample of only men.

An investigation with the participation of 140 North American stomated patients from the city of New York $^{13}$ presented similar results to this paper in terms of age, in which the study sample 
Table 4. Results of the statistical tests between the QoL score and the sociodemographic characteristics, of the stoma and previous preparation of the participants, Vila Real, Portugal $(n=100)$

\begin{tabular}{lcccc}
\hline Variables & Test & Test value (F) & Degrees of freedom & $\boldsymbol{p}$ \\
\hline QoL x sex & $\mathrm{T}$ & 0.462 & 98 & 0.645 \\
\hline QoL x age group & $\mathrm{T}$ & -1.404 & 98 & 0.163 \\
QoL x academic qualifications & Anova & 0.062 & 2 & 0.940 \\
QoL x socioeconomic level & Kruskal Wallis & 2.441 & 2 & 0.295 \\
QoL x etiology & $\mathrm{T}$ & 2.860 & 98 & $\mathbf{0 . 0 0 5}$ \\
QoL x type of ostomy & Kruskal Wallis & 6.679 & 2 & $\mathbf{0 . 0 3 5}$ \\
QoL x previous preparation & U Mann Whitney & 101.500 & & $\mathbf{0 . 0 0 0}$ \\
QoL x stoma appointment & $\mathrm{T}$ & 5.271 & 98 & $\mathbf{0 . 0 0 0}$ \\
\hline
\end{tabular}

was aged between 23 and 89 years and the mean age was of 65.02 years, mean slightly lower than the present study. The predominance of the female sex (59.3\%) and the higher academic qualifications in that study, as $39.3 \%$ of the sample had higher education, can be explained on the basis of cultural differences and because they are individuals from a great cosmopolitan city. The individuals included in our study belong to a typical rural population with its own characteristics and basic schooling. ${ }^{30}$

Another study with a sample of 215 people, performed in São Paulo city (Brazil), ${ }^{31}$ found that $51.6 \%$ of the individuals were males, aged over 50 years (73\%), married $(52.1 \%)$, mostly with the first cycle of basic education (48.4\%) and $80.9 \%$ had no occupation, which included the retired individuals and housewives, sociodemographic characteristics quite similar to those of our study.

The data on the characteristics of the ostomies are in line with the results of other studies carried out in this field, such as the one performed in the city of Lisbon (Portugal), ${ }^{32}$ where colostomies were also the most present type of intestinal elimination ostomy $(72.5 \%)$ and mostly definitive $(79,8 \%)$.

The study carried out in Brazil in the city of São Paulo ${ }^{31}$ presented a sample with characteristics of the ostomies similar to those of the participants of this study, in which $67.4 \%$ of intestinal ostomies corresponded to colostomy, $63.7 \%$ were definitive in nature and the predominant cause was cancer $(59,1 \%)$.

The study performed in New York (USA) ${ }^{13}$ presents results related to these parameters, slightly different from this one, more specifically, in the type of ostomies, with the largest number being ileostomies $(61.4 \%)$, all permanent (100\%), justified by the dominant etiology for the presence of an intestinal stoma in these patients, and ulcerative colitis (39.3\%), although followed by cancer $(27,9 \%)$.

In the study carried out with a sample of 51 ostomized persons in the city of Guarda, Beira Region in the countryside of Portugal, ${ }^{18}$ the majority of respondents had a colostomy $(96.0 \%)$ and a permanent colostomy $(90.2 \%)$, received preoperative information $(76.5 \%)$, and $35.7 \%$ had appealed to the stomatherapy nursing consultation. The characteristics of the colostomy coincide with those of this study, but in the mentioned investigation there is a marked rise in the number of respondents who participated in the stomatherapy nursing consultation, which may be due to the fact that it is more recent than this paper's and the consultations are in greater demand.

As to the stoma marking results, it was present in $72.9 \%$ of the subjects surveyed in the USA (New York), ${ }^{13}$ a percentage higher than that obtained in the present study. That value is in line with the fact that in that country, stomatherapy is an old reality, precisely since the 1960 s, being accessible to a greater percentage of patients. ${ }^{3}$ In the Portuguese reality the stomatherapy nursing consultation is still in implementation phase.

With respect to work activity, according to a survey carried out in New York $47.9 \%$ of the participants were working after the ostomy, however, $23.8 \%$ admitted that they had altered their work because of it, ${ }^{13}$ while in the present study almost all participants did not have any work activity and the percentage of stomatized individuals that changed their work activity due to this condition was very similar. The discrepancy between the two studies may be due to the cultural differences between the two peoples and to how they both react to this condition. However, the results of the present study are in agreement with the literature consulted, ${ }^{33}$ which states that the presence of an ostomy may be an element that incapacitates the person to develop or even maintain work activity, having a more negative character in man.

As to the impact of the ostomy on sexual activity, $58.2 \%$ of the ostomized sample investigated in Lisbon ${ }^{32}$ showed changes in the quality of their sexuality after the ostomy, reflected in the marital satisfaction, a percentage slightly higher than the present study. This dimension of human life was also addressed in the study conducted in the USA, ${ }^{13}$ as it was verified that $71.4 \%$ of the participants reduced their activity after surgery and $69 \%$ of the men admitted having erection problems or maintenance thereof, results that differ from the present study, both in the first percentage that is higher in that study, and in the second percentage that is higher in this study. 
Sexuality is an aspect that depends on many variables and on the reality of each person, which makes it difficult to explain these differences. However, it is in agreement with results presented in an integrative review study carried out in Brazil, which states that the presence of the stoma significantly interferes with sexual activity, affecting both sexes, and women may present libido loss and men decrease or absence of erection. ${ }^{34}$

In terms of diet, most of the participants in this study did not change their diet, but reported avoiding gas drinks (91\%) and eating snacks $(87 \%)$, which corroborate the Brazilian study, which reports food restriction and that many stomatized patients avoid eating foods that cause gas or are fast-digesting. ${ }^{34}$

In relation to the QoL average score of 0 to 10 points, it is lower than the study conducted in New York ${ }^{13}$ that was $7.56 \pm$ 1.59 points. This difference can be explained by the fact that the stomatherapy nursing consultation has been implemented in the USA for a longer period of time and the consultation in Portugal still does not give sufficient support to these users.

Although the study conducted in the city of Guarda (Portugal), ${ }^{18}$ had used the SF36 to evaluate the QoL of the respondents, it was found that $78.4 \%$ of the sample classified their QoL as excellent and reasonable, a percentage higher than the present study, and obtained on the scale an overall mean of 50.2 points, meaning a positive perception of the QoL, slightly above the midpoint.

In a study carried out in the city of Uberaba (MG-Brazil), ${ }^{35}$ with a sample of 850 elderly people, the majority perceived the QoL as good $(58.2 \%)$, which corresponds to the positive perception in the present study, in which a slightly higher percentage was obtained.

There were no statistically significant differences between the sociodemographic characteristics and the QoL in our study, as happened in the Guarda study (Portugal), ${ }^{18}$ except for schooling, since in this study the participants with higher education perceived better QoL in almost all the dimensions.

As in this study, in the study of Minas Gerais, ${ }^{35}$ there were no statistically significant differences between the QoL of the two age groups. However, when the statistical difference is verified between the mean of the QoL in relation to the previous marking of the stoma site, in our study we observed a statistically significant difference, with the ostomized individuals that had previous marking of the stoma mentioned having a better QoL, in the study conducted in the USA, ${ }^{13}$ on the other hand, no significant statistical differences were found. The explanation for this difference between the two studies may reside in the fact that the great majority of the sample of American stomatized individuals participate in the stomatherapy visit.

The results of the tests related to the influence of the previous preparation of the ostomized individuals and the information that they received before the surgery reveal both in this study and in the study of Guarda (Portugal), ${ }^{18}$ statistically significant differences in the two studies, with the best QoL to be perceived by the ostomized patients who were previously prepared, regarding nursing care, in the framework of the stomatherapy consultation.
This means that nursing care, within the nursing consultation, contributed to the improvement of QoL. These results also corroborate those obtained in a survey conducted in England, ${ }^{16}$ which showed that the preoperative nursing consultation reduced the complication rate, thus contributing to a better QoL.

The main limitations of this study are related to the fact that it is not a random sample and because it is a cross-sectional study. With the accomplishment of a longitudinal study it was possible to confirm the positive effect of the care given in the stomatherapy consultation in the participants' QoL.

\section{CONCLUSIONS AND IMPLICATIONS FOR PRACTICE}

The study participants' standard corresponds to male, elderly, married, with the first cycle of basic education, retired and the middle class. They have a permanent colostomy, whose etiology was the cancer, with previous preparation and consequent marking of the stoma in the stomatherapy nursing consultation.

The impact of the study on the Daily Living Activities (DLA) of the study participants was greater in the work activity, with $28 \%$ no longer working because of the ostomy; sexual activity was reduced by $48 \%$ and $88.7 \%$ of men reported having erection problems. The QoL of the participants may be considered to be reasonable.

There was no relationship between QoL and the sociodemographic characteristics of the participants. Regarding the relationship between QoL and the characteristics of the ostomies (etiology and type of ostomies), as well as the participation in the stomatherapy nursing consultation (previous preparation of the patient for the stoma, and previous scheduling of the stoma), the existence of this relationship was verified. This demonstrates that the preparation of the patient in the consultation and the nursing care provided are indispensable for the adaptation of the people to their new condition of life and, therefore, contributes to improve their QoL.

The accomplishment of this investigation allowed emphasizing the importance of nursing care, in the ambit of the stomatherapy Nursing consultation, in the accompaniment and personalized support to the person in the different phases of adaptation to its new condition of life.

These aspects arise as a challenge for the nurse, requiring an optimization and personalization of the nursing interventions adjusted to the specific needs of each person, facilitating the process of transition and qualification of the person for the self-care to the ostomy.

Given these results and considerations, it seems more than justified the existence of a stomatherapy consultation in the differentiated health care with protocols of reference for primary health care, facilitating the continuity of care in the community to the ostomized person. Therefore, this theme is included in the training plan for nurses who provide care in the functional health units of the health center groupings in the region. 
The importance of research for the improvement of the care provided to ostomized person, as well as their quality of life, has also emerged. Our study has contributed to motivate other investigations of this scope (not published), having led a group of researchers to replicate the research throughout the Portuguese territory, including islands, in order to further substantiate these results.

\section{ACKNOWLEDGMENTS}

This study had the financial support of CIEC (Research Centre on Child Studies), by the Strategic Project UID/ CED/00317/2013, through the National Funds through the FCT (Foundation for Science and Technology) and co-financed by European Regional Development Funds (FEDER) through the Competitiveness and Internationalization Operational Program (POCl) with the reference POCl-01-0145-FEDER-007562.

\section{REFERENCES}

1. Ferreira A, Seiça A, Morais I. Pessoa ostomizada. Enferm Cidadão. 2009;7(20):3-5.

2. United Ostomy Associations of America (UOAA). lleostomy new patient guide [on line]. Mission Viejo (CA): United Ostomy Associations of America. [Internet] 2012. [cited 2013 Jan 11]. Available from: https:// www.ostomy.org/?s=2.\%09United+Ostomy+Associations+of+Americ a+\%28UOAA\%29.+lleostomy+new+patient+guide+

3. United Ostomy Associations of America (UOAA). Colostomy guide [on line]. Kennebunk (ME): United Ostomy Associations of America. [Internet] 2011. [cited 2013 Jan 11]. Available from: http://www.ostomy. org/uploaded/files/ostomy_info/ColostomyGuide.pdf?direct=1

4. Santos V, Kimura M, Chaves E. Quality of life and coping of persons with temporary and permanente stomas. J Wound Ostomy Continence Nurs [Internet]. 2006 Sep/Oct; [cited 2017 Mar 8]; 33(5):503-9. Available from: https://www.ncbi.nlm.nih.gov/pubmed/17133138

5. International Agency for Research on Cancer (IARC). GLOBOCAN 2008: Cancer Incidence and Mortality Worldwide. Lyon (FR): IARC. [Internet] 2008. [cited 2013 Jan 11]. Available from: https://www.iarc. fr/en/media-centre/iarcnews/2010/globocan2008.php

6. Pinto IMS. Desenvolvimento da competência de autocuidado da pessoa com ostomia de eliminação intestinal: validação do formulário [Dissertação]. Porto: Escola Superior de Enfermagem do Porto; 2014.

7. Hendren S, Hammond K, Glasgow SC, Perry WB, Buie WD, Steele SR, et al. Clinical practice guidelines for ostomy surgery. Dis Colon Rectum [Internet]. 2015 Apr; [cited 2017 Nov 8]; 58(4):375-87. Available from: https://www.ncbi.nlm.nih.gov/pubmed/25751793

8. Oliveira AMP. Qualidade de vida da pessoa portadora de ostomia na Unidade Local de Saúde Nordeste [Dissertação]. Bragança: Instituto Politécnico de Bragança, Escola Superior de Saúde; 2016. Available from: https://bibliotecadigital.ipb.pt/bitstream/10198/13339/1/Tese\%20 Final\%20CD.pdf

9. Ciorogar G, Zaharie F, Ciorogar A, Birta D, Degan A, Balint I, et al. Quality of life outcomes in patients living with stoma. HVM Bioflux [Internet]. 2016; [cited 2018 May 30]; 8(3):137-40. Available from: http:// www.hvm.bioflux.com.ro/docs/2016.137-140.pdf

10. Liao C, Qin Y. Factors associated with stoma quality of life among stoma patients. Int J Nurs Sci [Internet]. 2014 Jun; [cited 2018 May 30]; 1(2):196-201. Available from: https://www.sciencedirect.com/science/ article/pii/S2352013214000428

11. Salomé GM, Almeida SA, Silveira MM. Quality of life and self-esteem of patients with intestinal stoma. J Coloproctol (Rio J) [Internet]. 2014 Oct/ Dec; [cited 2018 May 30];34(4):231-9. Available from: http://www.scielo. $\mathrm{br} /$ scielo.php?script=sci_arttext\&pid=S2237-93632014000400231
12. Nugent KP, Daniels P, Stewart B, Patankar R, Johnson CD. Quality of life in stoma patients. Dis Colon Rectum [Internet]. 1999 Dec; [cited 2017 Aug 15]; 42(12):1569-74. Available from: https://www.ncbi.nlm. nih.gov/pubmed/10613475

13. Youngberg DR. Individuals with a permanent ostomy: Quality of life, preoperative stoma site marking by an ostomy nurse, six peristomal complications, and out-of-pocket financial costs for ostomy management [Thesis]. New York: Teachers College, Columbia University;2010. [cited 2017 Dec 10]. Available from: https://pqdtopen. proquest.com/doc/756455421.html?FMT=ABS

14. Martins CG. Sexualidade da pessoa com ostomia de eliminação intestinal: que intervenção? [Dissertation]. Coimbra: Escola Superior de Enfermagem de Coimbra; 2013.

15. Morais I, Neves D, Seiça A. Caracterização da pessoa com complicações locais da ostomia e sua percepção sobre os cuidados de saúde recebidos. Nursing. 2009;21(251):28-30.

16. Rust J. Care of patients with stomas: the pouch change procedure. Nurs Stand. 2007 Oct 23;22(6):43-7. Available from: https://www.ncbi.nlm. nih.gov/pubmed/?term=16.\%09Rust+J.+Care+of+patients+with+sto mas $\% 3 A+$ the+pouch+change+procedure.+Nursing+Standard.+200 $9 \% 3 B+22(6) \% 3 A+43-47$

17. Santos VLCG. Cuidando do estomizado: Análise da trajectória no ensino, pesquisa e extensão [Thesis]. São Paulo: Escola de Enfermagem da Universidade de São Paulo; 2006. [cited 2012 Sep 20]. Available from: http://www.teses.usp.br/teses/disponiveis/ livredocencia/7/tde-15092006-145018/en.php

18. Pinto MIAC. A Pessoa Ostomizada: Um estudo sobre qualidade de vida [Dissertation]. Guarda: Escola Superior de Saúde, Instituto Politécnico da Guarda; 2012.

19. Antunes ESSB. Cuidar em parceria: O enfermeiro, a pessoa idosa $e$ sua família, na fase pré e pós colostomia [Internship report]. Lisboa: Escola Superior de Enfermagem de Lisboa; 2016. Available from: https://comum.rcaap.pt/bitstream/10400.26/16509/1/Tese\%20FINAL. pdf

20. Portela J. Preparação pré-operatória com a pessoa com estomia: promover uma transição saudável [Project paper report]. Setúbal: Escola Superior de Saúde, Instituto Politécnico de Setúbal; 2015. Available from: http://hdl.handle.net/10400.26/11259

21. Direção-Geral da Saúde (DGS). Norma 014/2016. Indicações clínicas e intervenções nas ostomias de alimentação em idade pediátrica e no adulto. Lisboa: DGS [Internet]. 2016; [cited 2018 May 30]. Available from: http://www.arsnorte.min-saude.pt/wp-content/uploads/sites/3/2017/12 Norma_014-2016_Ostomizados.pdf

22. Fortin MF, Côté J, Fillion F. Fundamentos e etapas do processo de investigação. Loures: Lusodidacta; 2009.

23. Apóstolo J. Instrumentos para avaliação em geriatria (Geriatric Instruments). [Internet]. Coimbra: Escola Superior de Enfermagem de Coimbra; 2012. [cited 2012 Sep 20]. Available from: file://C:/Users/ susana/Downloads/Instrumentos_de_Avalia\%C3\%A7\%C3\%A3o_ Geri\%C3\%A1trica_MAIO_12.pdf

24. Grant M, Ferrell B, Dean G, Uman G, Chu D, Krouse R. Revision and psychometric testing of the city of Hope Quality of Life-Ostomy Questionnaire. Qual Life Res [Internet]. 2004 Oct; [cited 2017 Aug 15]; 13(8):1445-57. Available from: https://www.ncbi.nlm.nih.gov/ pubmed/15503840

25. Kimura M. Tradução para o português e validação do Quality of Life Index de Ferrans e Powers [Free teaching thesis] [Internet]. São Paulo: Escola de Enfermagem da Universidade de São Paulo; 1999. [cited 2012 Sep 20]. Available from: http://bdpi.usp.br/single. php?_id=001041949

26. Miranda LSG. A importância da consulta de Enfermagem de estomaterapia na qualidade de vida da pessoa ostomizada na comunidade [Dissertation]. Vila Real: Universidade de Trás-osMontes e Alto Douro; 2013. Available from: https://repositorio.utad.pt/ bitstream/10348/2919/1/msc_Isgmiranda.pdf

27. Marôco J. Análise estatística com o SPSS Statistics. Pêro Pinheiro (PT): Report Number; 2014. 
28. Instituto Nacional de Estatística (INE). Censos 2011 resultados definitivos - Portugal. Lisboa (PT): INE; 2012.

29. Reis FF, Carvalho AAS, Santos CSB, Rodrigues VMCP. Percepção sobre o apoio social do homem colostomizado na Região Norte de Portugal. Esc Anna Nery [Internet]. 2014 Oct/Dec; [cited 2015 Mar 15]; 18(4):570-7. Available from: http://www.scielo.br/pdf/ean/v18n4/14148145-ean-18-04-0570.pdf

30. Pordata. Base de Dados Portugal Contemporâneo. Lisboa (PT): Pordata; 2013 [Internet]. Available from: www.pordata.pt

31. Gomboski G. Adaptação cultural e validação do City of Hope Quality of Life - Ostomy Questionaire para a língua portuguesa no Brasil [Dissertation]. São Paulo: Universidade de São Paulo; 2010. [cited 2013 Sep 30]. Available from: http://www.teses.usp.br/teses/ disponiveis/7/7139/tde-01082011-074203/pt-br.php
32. Menezes MPNC. Satisfação conjugal, auto-estima e imagem corporal em indivíduos ostomizados [dissertação]. Lisboa (PT): Faculdade de Psicologia e Ciências da Educação, Universidade de Lisboa; 2008.

33. Gomes CG, Santos FMP, Ferreira VL. Vivências de Pessoas Ostomizadas com Doença de Crohn. Rev Ref. 2010;12:19-34. Available from: file:///C:/Users/susana/Downloads/2.\%C2\%BA_Classificado.pdf

34. Ribeiro JMC. Qualidade de vida de pessoas com ostomia intestinal: revisão integrativa [Completion of course work] [Internet]. Brasília: Universidade de Brasília, Faculdade de Ciências da Saúde Departamento de Enfermagem; 2015. [cited 2017 Mar 8]. Available from: http://bdm.unb. br/bitstream/10483/10685/1/2015_JarineManuelleCastroRibeiro.pdf

35. Tavares DMS, Gomes NC, Dias FA, Santos NMF. Fatores associados à qualidade de vida de idosos com osteoporose residentes na zona rural. Esc Anna Nery [Internet]. 2012 Apr/Jun; [cited 2017 Mar 8]; 16(2):371-8. Available from: http://www.scielo.br/scielo.php?script=sci_arttext\&pid $=$ S1414-81452012000200023 